\title{
Comparison of growth traits of eight beef cattle breeds in the Czech Republic
}

\author{
Dedicated to Prof. Dr. agr. habil. Dr. h. c. mult. Georg Schönmuth on the occasion of \\ his $75^{\text {th }}$ birthday
}

\begin{abstract}
Summary
Eight beef cattle breeds, Angus (A), Blonde d' Aquitaine (BA), Charolais (C), Czech Pied (CP), Hereford (H), Limousin (L), Piemontese (P) and Simmental (S), were analysed for the following calf traits: birth weight (BW), 210- and 365-day weight ( $210 \mathrm{~W}, 365 \mathrm{~W})$ and average daily gains from birth to 210 days (ADG1), from 210 to 365 days (ADG2) and from birth to 365 days (ADG3). Phenotypic parameters were estimated by linear model procedures including the fixed effects of year of birth (1992-1998), herd, sex (male, female), calf number (single, twin), parity and random sire effects. Literature values of heritability estimates were used to derive genetic standard deviations and genetic range for comparison of genetic variation within and between breeds. The means of Blonde d' Aquitaine were highest for all growth traits except for BW, followed by Charolais and Simmental, then Angus, Czech Pied and Limousin with intermediate values and Piemontese and Hereford with lowest growth except for BW in Piemontese and ADG1 in Hereford. Blonde d' Aquitaine also showed high standard deviations for most growth traits except for BW, whereas for Limousin and Piemontese low standard deviations were estimated and for other breeds no consistent pattern was observed. Coefficients of variation were generally high for Hereford and low for Angus. Hypothetical frequency curves were used for comparison of genetic variation within breeds and between breeds. Comparison of extreme and average breeds showed ranges of genetic levels between 79 and $154 \%$ of the average breed level thus indicating the large overall genetic variation for growth traits in beef cattle. Between-breed selection with immediate impact, but steady erosion by time, as well as within-breed selection with slow but steady increase and renewed variation should both be applied for optimal exploitation of genetic resources in the beef industry.
\end{abstract}

Key Words: beef cattle breeds, growth traits, genetic analysis, breed comparison

\section{Zusammenfassung}

Titel der Arbeit: Vergleich von Wachstumsmerkmalen bei acht Fleischrinderrassen in der Tschechischen Republik

Acht Fleischrinderrassen, Angus (A), Blonde d' Aquitaine (BA), Charolais (C), Tschechisches Fleckvieh (CP), Hereford (H), Limousin (L), Piemontese (P) and Simmental (S), wurden folgende Merkmale analysiert: Geburtsgewicht (BW), 210- und 365-Tage Gewicht (210W, 365W) und durchschnittliche tägliche Zunahmen von der Geburt bis zu 210 Tagen (ADG1), von 210 bis zu 365 Tagen (ADG2) und von der Geburt bis zu 365 Tagen (ADG3). Die phänotypischen Parameter wurden mit einem linearen Modell unter Einbeziehung der fixen Effekten Geburtsjahr (1992-1998), Herde, Geschlecht (weiblich, männlich), Geburtstyp (Einlinge, Zwillinge), Kalbenummer und des zufälligen Vatereffekts geschätzt. Heritabilitätsschätzwerte aus der Literatur wurden für die Ableitung der genetischen Standardabweichungen genutzt. Diese Standardabweichungen und die genetische Streubreite der Mittelwerte dienten zum Vergleich der genetischen Variation zwischen und innerhalb Rassen. Die Rasse Blonde d'Aquitaine hatte die höchsten Mittelwerte für alle Wachstumsmerkmale außer dem Geburtsgewicht, darauf folgten die Rassen Charolais und Simmental. Die Rassen Angus, Tschechisches Fleckvieh und Limousin wiesen mittlere Werte auf und die Rassen Piemontese und Hereford hatten die niedrigsten Merkmalswerte ausser für das Geburtsgewicht bei der Rasse Piemontese und ADG1 bei Hereford. Die höchsten Standard- 
abweichungen wurden für alle Merkmale ausser dem Geburtsgewicht bei der Rasse Blonde d' Aquitaine festgestellt, während die Rassen Limousin und Piemontese die niedrigsten Standardabweichungen aufwiesen. Bei den übrigen Rassen konnten für die Wachstumsmerkmale keine Gesetzmässigkeiten festgestellt werden. Allgemein waren die Variationskoeffizienten bei Hereford und Angus hoch. Hypothetische Häufigkeitsverteilungen wurden für den Vergleich der genetischen Variation zwischen und innerhalb der Rassen genutzt. Beim Vergleich von drei Rassen mit extremer und mittlerer Merkmalausprägung wurde eine Variationsbreite der genetischen Werte zwischen 79 und $154 \%$ des Rassendurchschnittes festgestellt, was auf eine große genetische Gesamtvariation der Wachstumsmerkmale hinweist. Die Selektion zwischen den Rassen führt zu einer sofortigen Verbesserung des genetischen Potentials, die aber mit der Zeit stetig abnimmt. Die Selektion innerhalb der Rassen ist ein langwieriger Prozess mit langfristiger genetischer Leistungssteigerung. Die Anwendung beider Selektionsformen führt zur optimalen Nutzung der genetischen Ressourcen in der Fleischrinderproduktion.

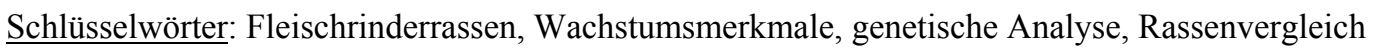

\section{Introduction}

Large imports of beef cattle breeds (Angus, Blonde d'Aquitaine, Galloway, Hereford, Highland, Charolais, Limousin, Piemontese, Salers and Simmental) were characteristic since 1990 (JAKUBEC et al., 1998). However the first beef cattle imports (800 Hereford heifers) were realized from Canada in 1974 and 1987. The mentioned breeds are representing various biological types, which are well adapted to various environments and beef production systems representing different feed, climate, land resources and marketing situation. Breed diversity can be used to fit the genetic resources quickly to production and market requirements.

Identifying superior breeds would be simple if adequate life-cycle performance data were available on large representative samples of breed of potential interest. Comparisons would need to be made among cattle breeds raised under the same conditions and preferably over a range of conditions to evaluate the possibility of genotype $\mathrm{x}$ environment interactions.

Unfortunately, such ideal comparisons require a large input of financial resources. Multibreed comparisons in beef cattle are rare. A multibreed cattle experiment involving 25 British breeds was set up by THIESSEN et al. (1984) to study genetic variation between breeds and genetic inter-breed relationships for a wide spectrum of traits in order to examine the problems of between-breed testing and selection. They estimated the intraclass correlation ( $\rho)$ according to TAYLOR $(1976 \mathrm{a}, \mathrm{b})$ which expressed the variation between breeds as a proportion of the total variation. Results were presented for body weight and daily weight gain over a range of 12 to 72 weeks. The intraclass correlation $(\rho)$ for body weight was much higher than for daily gain at all ages. The correlation for body weight rose from $\rho=0.44$ at 12 weeks of age to $\rho=0.68$ at 48 weeks of age. For higher age, $\rho$ increased only marginally to $\rho=0.71$ at 72 weeks of age. For daily gain, $\rho$ increased markedly from the first interval of 1224 weeks ( $\rho=0.29$ ) to a maximum of $\rho=0.52$ in the 24 to 36 week interval (when average daily weight gain was also at its maximum); for higher age, the value declined continuously to a value of approximately 0.2 , for daily gain measured over 12 week intervals, there was in general less variation between breeds than within breeds. CUNDIFF et al. (1986) analyzed the birth weight of 4,639 calves sired by 290 bulls of 14 Bos taurus breeds mated to Hereford and Angus cows. Variance components were estimated for breed of sire, sire within breed of sire and progeny within sire random effects. They found a much higher proportion of total phenotypic variance due to breeds $(0.617)$ than due to sires within breeds $(0.176)$. The total heritability (between 
and within breed heritability) was $h_{t}^{2}=0.80$ and the within breed heritability $h_{w}^{2}=$ 0.46. An exhaustive multibreed comparison was carried out in four cycles between 1970 and 1990 within the Germ Plasm Evaluation (GPE) program at the USDA Roman L. Hruska U. S. Meat Animal Research Center, Clay Center, Nebraska, USA. Results from this GPE program for body weights and daily gains from birth to 400 days are reviewed on relative amounts of genetic variation between and within breeds in pre- and postweaning growth (CUNDIFF et al., 1986a, b; KOCH et al., 1989; SZABÓ et al., 1990). Topcross performance of 26 different sire breeds have been evaluated in $F_{1}$ calves out of Hereford and Angus dams. RENAND et al. (1992) presented a survey which involved a large scale comparison of beef cattle breeds. They are an important part of genetic resources available to change production potential. In contrast to slow changes associated with intrabreed selection, average differences among breeds or breed crosses can be exploited rapidly by capitalizing on many years of cumulative change. In the Czech Republic most of the performance data recorded are restricted to one breed at a single location (herd). On the other hand almost all beef breeds are kept in quite a number of environmental situations.

The main objective of the present study was the analysis and comparison of pre- and postweaning growth traits of important beef breeds in the Czech Republic representing different biological types.

\section{Material and Methods}

The following growth traits of the beef cattle breeds Angus ( $n=947)$, Blonde d'Aquitaine $(\mathrm{n}=313)$, Czech Pied $(\mathrm{n}=201)$, Hereford $(\mathrm{n}=983)$, Charolais $(\mathrm{n}=$ $1631)$, Limousin $(n=515)$, Piemontese $(n=194)$ and Simmental $(n=135)$ were recorded in the Czech Republic from 1992 to 1998: birth weight, 210-day weight, 365day weight and average daily gains (birth-210 days, 210-365 days, birth-365 days). In a preceding study (JAKUBEC et al., 2000) the growth traits were analysed by linear models procedures, with respect to the following fixed factors: year of birth, herd, sex (male, female), calf number (single, twin), parity and the random sire effect. Because artificial insemination is rarely used in the herds the breeds mentioned were kept and tested in separate herds, i.e. the between breed comparison was not carried out in a single location. On the other hand almost all beef breeds were kept in a lot of environmental situations from lowlands to highlands, from foot-hills to mountains. The calves were reared and fattened from birth to 365 days in field conditions. The beef cattle breeds were mainly kept in marginal regions of the Czech Republic where a high portion of the feed was forage, i.e. under extensive management. Beef cattle and sheep thereby contribute to the conservation and effective use of this land by converting this large feed resource into food for human use.

Comparisons of breeds and traits were based on the overall means $(\mu)$, phenotypic standard deviations $\left(\sigma_{\mathrm{P}}\right)$ and coefficients of variation $(\mathrm{cv})$. The phenotypic parameters were obtained in the preceding analysis of these breeds by the generalized least squares method (JAKUBEC et al., 2000). Genetic standard deviations for comparison of the genetic variability of breeds were derived from heritabilities and phenotypic standard deviations. For all breeds the same estimates of heritability coefficients were used according to MÉNISSIER and FRISCH (1992) and RENAND et al. (1992). 


\section{Results and Discussion}

Least squares means, phenotypic standard deviations and coefficients of variation of the growth traits are presented in Table 1 and 2 . The overall means of weights and daily gains are also presented in Figure 1 and 2 . Within breed genetic standard deviations $\left(\hat{\sigma}_{G}, 3 \hat{\sigma}_{G}\right)$ for weights and daily gains from birth to 365 days are included in Table 3 . The genetic range (variation within breeds) for all growth traits $\left(\hat{\mu} \pm 3 \hat{\sigma}_{G}\right)$ with the maximum and minimum performance can be taken from Table 4 and 5 . Both tables are complemented by Figure 3 and 4. Hypothetical frequency curves based on the normal distribution and the genetic standard deviations were used for comparing the weights and daily gains from birth to 365 days age for three breeds representing the average and both extremes. The frequency curves reflect the genetic variation within breeds whereas the distances between breed means designate the variation between breeds for all growth traits.

Table 1

Least squares means $(\hat{\mu})$, phenotypic standard deviations ( $\left.\hat{\sigma}_{\mathrm{P}}\right)$ and coefficients of variation (cv) for weights (kg) from birth to 365 days [Least squares-Mittelwerte $(\hat{\mu})$, phänotypische Standardabweichungen $\left(\hat{\sigma}_{P}\right)$ und Variationskoeffizienten (cv) für Gewichte von der Geburt bis zu 365 Tagen]

\section{Weight at}

\begin{tabular}{|c|c|c|c|c|c|c|c|c|c|}
\hline \multirow[t]{2}{*}{ Breed } & \multicolumn{3}{|c|}{ Birth } & \multicolumn{3}{|c|}{210 days } & \multicolumn{3}{|c|}{365 days } \\
\hline & $\hat{\mu}$ & $\hat{\sigma}_{\mathrm{P}}$ & $\mathrm{CV}$ & $\hat{\mu}$ & $\hat{\sigma}_{\mathrm{P}}$ & $\mathrm{CV}$ & $\hat{\mu}$ & $\hat{\sigma}_{\mathrm{P}}$ & $\mathrm{CV}$ \\
\hline$\overline{\text { Czech Pied }}$ & 33.26 & 3.25 & 9.77 & 234.08 & 31.80 & 13.59 & 375.78 & 48.21 & 12.83 \\
\hline Angus & 29.22 & 3.37 & 11.53 & 241.42 & 29.05 & 12.03 & 379.50 & 44.61 & 11.75 \\
\hline B.d'Aquitaine & 35.09 & 4.61 & 13.14 & 275.08 & 34.66 & 12.60 & 424.38 & 58.55 & 13.80 \\
\hline Hereford & 24.03 & 2.92 & 12.15 & 195.52 & 35.42 & 18.12 & 308.27 & 50.95 & 16.53 \\
\hline Charolais & 35.79 & 4.90 & 13.69 & 271.98 & 33.05 & 12.15 & 415.59 & 52.73 & 12.69 \\
\hline Limousin & 29.19 & 3.39 & 11,61 & 216.06 & 29.01 & 13.43 & 348.16 & 45.02 & 12.93 \\
\hline Piemontese & 37.87 & 4.71 & 12,44 & 207.23 & 30.99 & 14.95 & 341.58 & 42.38 & 12.41 \\
\hline Simmental & 28.29 & 3.63 & 12,83 & 260.72 & 35.45 & 13.60 & 418.50 & 53.74 & 12.84 \\
\hline
\end{tabular}

Table 2

Least squares means $(\hat{\mu})$, phenotypic standard deviations $\left(\hat{\sigma}_{\mathrm{P}}\right)$ and coefficients of variation (cv) for daily gains $(\mathrm{kg})$ from birth to 365 days [Least squares-Mittelwerte $(\hat{\mu})$, phänotypische Standardabweichungen $\left(\hat{\sigma}_{P}\right)$ und Variationskoeffizienten (cv) für Tageszunahmen (kg) von der Geburt bis zu 365 Tagen]

$$
\text { Daily gains }
$$

Breed

Birth- 210 days

Birth-365 days

210-365 days

\begin{tabular}{lllllllllll} 
& $\hat{\mu}$ & $\hat{\sigma}_{P}$ & $\mathrm{CV}$ & $\hat{\mu}$ & $\hat{\sigma}_{P}$ & $\mathrm{CV}$ & $\hat{\mu}$ & $\hat{\sigma}_{P}$ & $\mathrm{CV}$ \\
\hline Czech Pied & 0.956 & 0.151 & 15,79 & 0.938 & 0.132 & 14.07 & 0.914 & 0.253 & 27.68 \\
Angus & 1.010 & 0.138 & 13.66 & 0.960 & 0.122 & 12.71 & 0.891 & 0.248 & 27.83 \\
B.d'Aquitaine & 1.143 & 0.163 & 14.26 & 1.094 & 0.159 & 14.53 & 1.028 & 0.280 & 27.24 \\
Hereford & 0.817 & 0.167 & 20.44 & 0.779 & 0.138 & 17.72 & 0.727 & 0.258 & 35.49 \\
Charolais & 1.125 & 0.156 & 13.87 & 1.041 & 0.143 & 13.74 & 0.926 & 0.265 & 28.62 \\
Limousin & 0.890 & 0.138 & 15.51 & 0.874 & 0.123 & 14.07 & 0.852 & 0.223 & 26.17 \\
Piemontese & 0.806 & 0.152 & 18.86 & 0.832 & 0.116 & 13.94 & 0.867 & 0.211 & 24.34 \\
Simmental & 1.107 & 0.169 & 15.27 & 1.069 & 0.147 & 13.10 & 1.018 & 0.282 & 27.70 \\
\hline
\end{tabular}

Genetic standard deviations $\left(\sigma_{G}\right)$ were obtained by multiplying the phenotypic standard deviations with the square root of the heritability coefficient (h). Heritabilities for the preweaning traits of the beef breeds have not yet been estimated in the Czech 
Birth weight

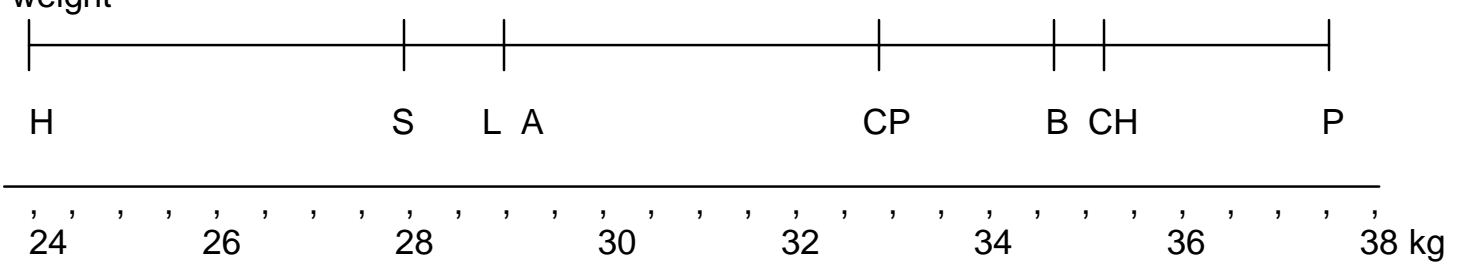

210-days weight

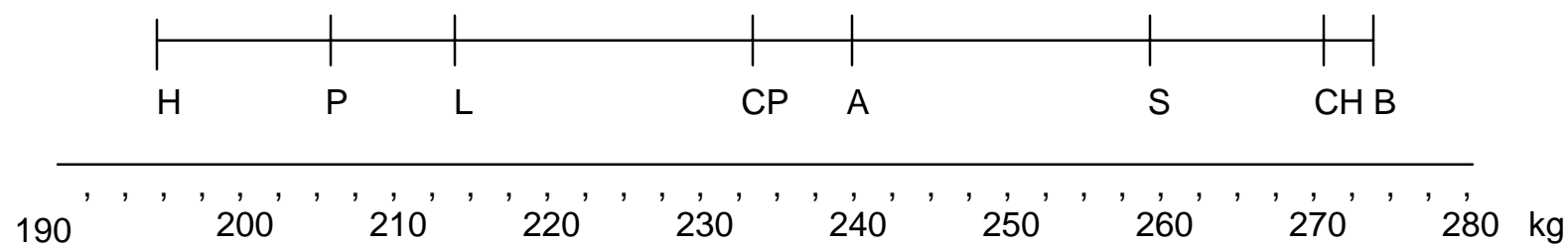

365-days weight

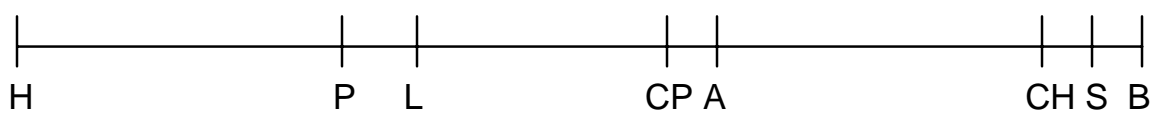

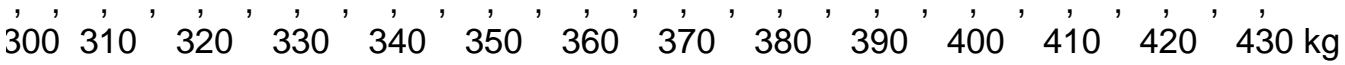

Fig. 1: Breed comparison of body weights from birth to 365 days [Rassengewichtsvergleich von der Geburt bis zu 365 Tagen]

Daily gains from birth to 210 days

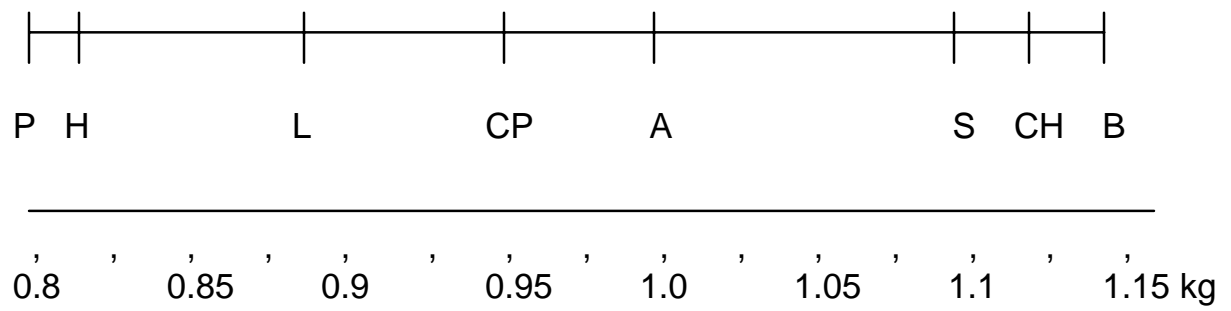

Daily gains from birth to 365 days

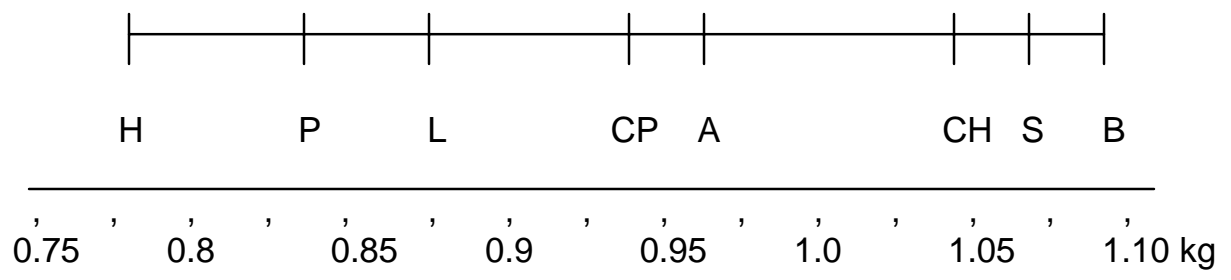

Daily gains from 210 to 365 days

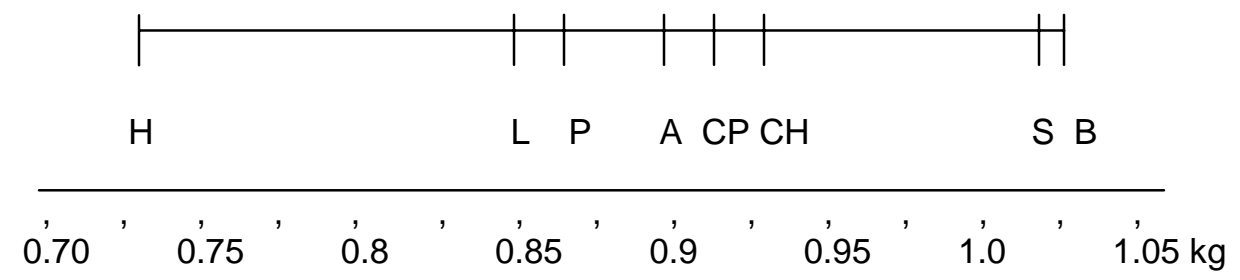

Fig. 2: Breed comparison of daily gains from birth to 365 days [Rassenvergleich für Tageszunahmen von der Geburt bis zu 365 Tagen] 
Republic. Therefore the heritability estimates and their square roots were adopted from the reviews of MÉNISSIER and FRISCH (1992) and RENAND et al. (1992). For the preweaning weights (at birth and at 210-days) the value of $h=0.5$, for 365-day weight $h=0.6$, for average daily gain from birth to 210 days $h=0.55$ and for average daily gains from birth to 365 days and from 210 to 365 days $\mathrm{h}^{2}=0.65$ was used.

Table 3

Within breed genetic standard deviations $\left(\hat{\sigma}_{G}, 3 \hat{\sigma}_{G}\right)$ for weights and daily gains from birth to 365 days $(\mathrm{kg})$ [Genetische Standardabweichungen innerhalb der Rassen $\left(\hat{\sigma}_{G}, 3 \hat{\sigma}_{G}\right)$ für Gewichte und Tageszunahmen von der Geburt bis zu 365 Tagen]

\begin{tabular}{|c|c|c|c|c|c|c|c|c|c|c|c|c|}
\hline \multirow[t]{2}{*}{ Breed } & \multicolumn{4}{|c|}{$\begin{array}{c}\text { Weight at } \\
210 \text { days } \\
(\mathrm{h}=0.5)\end{array}$} & \multicolumn{2}{|c|}{$\begin{array}{c}365 \text { days } \\
(\mathrm{h}=0.6)\end{array}$} & \multicolumn{2}{|c|}{$\begin{array}{l}\text { Birth-210 d. } \\
(\mathrm{h}=0.55)\end{array}$} & \multicolumn{2}{|c|}{$\begin{array}{c}\text { Daily gains } \\
\text { Birth-365 d. } \\
(\mathrm{h}=0.65)\end{array}$} & \multicolumn{2}{|c|}{$\begin{array}{l}210-365 \mathrm{~d} \\
(\mathrm{~h}=0.65\end{array}$} \\
\hline & $\hat{\sigma}_{G}$ & $3 \hat{\sigma}_{G}$ & $\hat{\sigma}_{G}$ & $3 \hat{\sigma}_{G}$ & $\hat{\sigma}_{G}$ & $3 \hat{\sigma}_{G}$ & $\hat{\sigma}_{G}$ & $3 \hat{\sigma}_{G}$ & $\hat{\sigma}_{G}$ & $3 \hat{\sigma}_{G}$ & $\hat{\sigma}_{G}$ & $3 \hat{\sigma}_{G}$ \\
\hline Czech Pied & 1.63 & 4.88 & 15.90 & 47.70 & 28.93 & 86.78 & 0.083 & 0.249 & 0.086 & 0.258 & 0.164 & 0.492 \\
\hline Angus & 1.69 & 5.06 & 14.53 & 43.58 & 26.77 & 80.30 & 0.076 & 0.228 & 0.080 & 0.238 & 0.161 & 0.484 \\
\hline B.d'Aquit. & 2.31 & 6.92 & 17.33 & 51.99 & 35.13 & 105.39 & 0.090 & 0.269 & 0.103 & 0.310 & 0.182 & 0.546 \\
\hline Hereford & 1.46 & 4.38 & 17.71 & 53.13 & 30.57 & 91.71 & 0.092 & 0.276 & 0.090 & 0.269 & 0.168 & 0.503 \\
\hline Charolais & 2.45 & 7.35 & 16.53 & 49.58 & 31.64 & 94.91 & 0.086 & 0.257 & 0.093 & 0.279 & 0.172 & 0.517 \\
\hline Limousin & 1.70 & 5.09 & 14.51 & 43.52 & 27.01 & 81.04 & 0.076 & 0.228 & 0.080 & 0.238 & 0.145 & 0.435 \\
\hline Piemontese & 2.36 & 7.07 & 15.50 & 46.49 & 25.43 & 76.28 & 0.084 & 0.251 & 0.075 & 0.226 & 0.137 & 0.411 \\
\hline Simmental & 1.82 & 5.45 & 7.73 & 53.18 & 32.24 & 96.73 & 0.093 & 0.279 & 0.096 & 0.287 & 0.183 & 0.550 \\
\hline
\end{tabular}

Table 4

Least squares means and genetic range of breeds for weights at birth, 210 and 365 days [Least squares Mittelwerte und die genetische Reihenfolge der Rasssen für das Gewicht bei Geburt, in 210 und 365 Tagen]

\begin{tabular}{|c|c|c|c|c|c|c|c|}
\hline \multirow{3}{*}{ Breeds } & \multicolumn{7}{|c|}{ Weight at } \\
\hline & Birth & \multicolumn{3}{|c|}{210 days } & \multicolumn{3}{|c|}{365 days } \\
\hline & $\hat{\mu}-3 \hat{\sigma}_{G} \quad \hat{\mu} \quad \hat{\mu}+3 \hat{\sigma}_{G}$ & $\hat{\mu}-3 \hat{\sigma}_{G}$ & $\hat{\mu}$ & $\hat{\mu}+3 \hat{\sigma}_{G}$ & $\hat{\mu}-3 \hat{\sigma}_{G}$ & $\hat{\mu}$ & $\hat{\mu}+3 \hat{\sigma}_{G}$ \\
\hline Czech Pied & $\begin{array}{lll}28.38 & 33.26 & 38.14\end{array}$ & 186.38 & 234.08 & 281.78 & 289.00 & 375.78 & 462.56 \\
\hline Angus & $\begin{array}{lll}24.16 & 29.22 & 34.28\end{array}$ & 197.84 & 241.42 & 285.00 & 299.20 & 379.50 & 459.80 \\
\hline B.d'Aquit. & $\begin{array}{lll}28.17 & 35.09 & 42.01\end{array}$ & 223.09 & 275.08 & 327.07 & 318.99 & 424.38 & 529.77 \\
\hline Hereford & $\begin{array}{lll}19.65 & 24.03 & 28.41\end{array}$ & 142.39 & 195.52 & 248.65 & 216.56 & 308.27 & 399.98 \\
\hline Charolais & $28.44 \quad 35.79$ & 222.40 & 271.98 & 321.56 & 320.68 & 415.59 & 510.50 \\
\hline Limousin & $24.10 \quad 29.19$ & 172.54 & 216.06 & 259.58 & 262.12 & 348.16 & 429.20 \\
\hline Piemontese & $\begin{array}{lll}30.80 & 37.87 & 44.94\end{array}$ & 160.74 & 207.23 & 253.72 & 265.30 & 341.58 & 417.86 \\
\hline Simmental & $22.84 \quad 28.29 \quad 33.74$ & 207.54 & 260.72 & 313.90 & 321.77 & 418.50 & 515.23 \\
\hline
\end{tabular}

Hereford cattle showed the lowest overall means in all traits with the exception of the daily gains from birth to 210 days. The Piemontese calves had the highest birth weight $(37.87 \mathrm{~kg})$ and exceeded the Blonde $\mathrm{d}^{\prime}$ Aquitaine and Charolais slightly for this trait. But for all other traits (body weights and daily gains) very low values were recorded in Piemontese. Angus, Czech Pied and Limousin displayed average values for all traits. The highest overall means for all traits with the exception of birth weight were recorded in Blonde d'Aquitaine. Charolais and Simmental showed only moderately slower weigths at 210 and 365 days and for all gains than Blonde d'Aquitaine.

The Hereford breed showed a low standard deviation for birth weight. Despite of this fact, for all other traits the standard deviations and coefficients of variation were among the highest value. The standard deviation was low in Limousine for all growth traits and very high in Blonde d'Aquitaine, while the coefficient of variation for the 
same traits of both breeds showed average values. On the contrary, low standard deviations and coefficients of variation for all traits were recorded in the Angus breed. The rest of the breeds showed no regularity of standard deviations and coefficients of variation for growth traits.
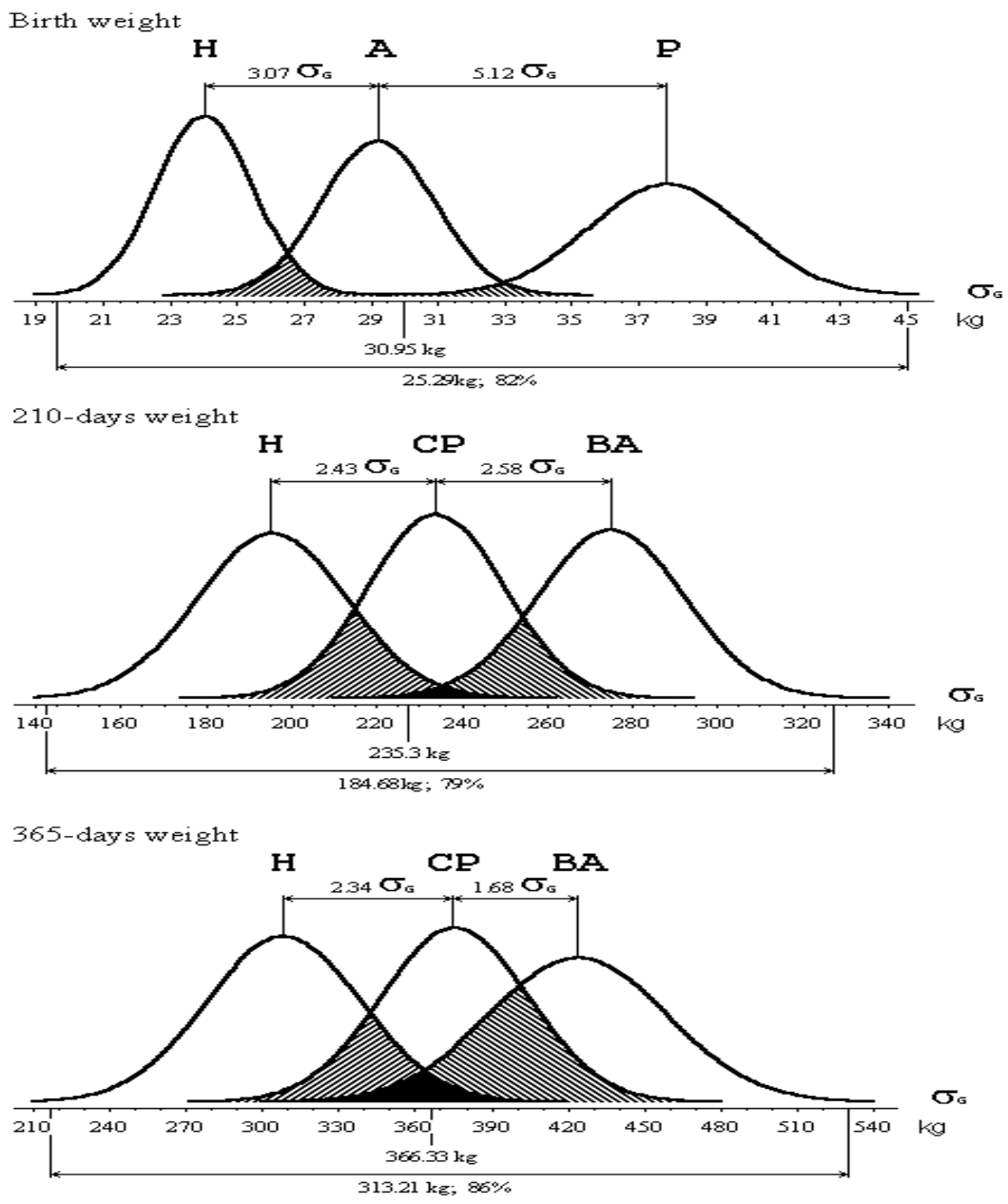

Fig. 3: Frequency curves of three breeds characterizing minimum, maximum and average weights (variation between and within breeds) [Normalverteilungskurven von drei Rassen mit minimalen, maximalen und durchschnittlichen Gewichten (Variation innerhalb und zwischen Rassen)]

Table 5

Least squares means and genetic range of breeds for daily gains from birth to 365 days [Least squaresMittelwerte und die genetische Reihenfolge der Rassen für die Tageszunahmen von der Geburt bis zu 365 Tagen]

\begin{tabular}{|c|c|c|c|c|c|c|c|c|c|}
\hline \multirow{3}{*}{ Breeds } & \multicolumn{9}{|c|}{ Daily gains } \\
\hline & \multicolumn{3}{|c|}{ Birth - 210 days } & \multicolumn{3}{|c|}{ Birth - 365 days } & \multicolumn{3}{|c|}{210 - 365 days } \\
\hline & $\hat{\mu}-3 \hat{\sigma}_{G}$ & $\hat{\mu}$ & $\hat{\mu}+3 \hat{\sigma}_{G}$ & $\hat{\mu}-3 \hat{\sigma}_{G}$ & $\hat{\mu}$ & $\hat{\mu}+3 \hat{\sigma}_{G}$ & $\hat{\mu}-3 \hat{\sigma}_{G}$ & $\hat{\mu}$ & $\hat{\mu}+3 \hat{\sigma}_{G}$ \\
\hline Czech Pied & 0.707 & 0.956 & 1.205 & 0.680 & 0.938 & 1.196 & 0.422 & 0.914 & 1.406 \\
\hline Angus & 0.782 & 1.010 & 1.238 & 0.720 & 0.960 & 1.198 & 0.407 & 0.891 & 1.375 \\
\hline B.d'Aquit. & 0.874 & 1.143 & 1.412 & 0.784 & 1.094 & 1.404 & 0.482 & 1.028 & 1.574 \\
\hline Hereford & 0.541 & 0.817 & 1.093 & 0.510 & 0.779 & 1.048 & 0.224 & 0.727 & 1.230 \\
\hline Charolais & 0.868 & 1.125 & 1.382 & 0.762 & 1.041 & 1.320 & 0.409 & 0.926 & 1.443 \\
\hline Limousin & 0.662 & 0.890 & 1.118 & 0.636 & 0.874 & 1.112 & 0.417 & 0.852 & 1.287 \\
\hline Piemontese & 0.555 & 0.806 & 1.057 & 0.606 & 0.832 & 1.058 & 0.456 & 0.867 & 1.278 \\
\hline Simmental & 0.828 & 1.107 & 1.386 & 0.782 & 1.069 & 1.356 & 0.468 & 1.018 & 1.568 \\
\hline $\begin{array}{l}\text { Average of } \\
\text { extremes }\end{array}$ & \multicolumn{3}{|c|}{0.980} & \multicolumn{3}{|c|}{0.937} & \multicolumn{3}{|c|}{0.878} \\
\hline
\end{tabular}


From Figure 3 it is evident that the frequency curves of Hereford and Piemontese for the birth weight did not overlap at all. The left half of the Angus frequency curve overlapped with the right half of the Hereford frequency curve and the right half of the Angus frequency curve overlapped with the left half of the Piemontese frequency distribution. The Angus birth weight was placed in the centre between the two extreme breeds. The genetic range $\left(\hat{\mu} \pm 3 \hat{\sigma}_{G}\right)$ amounted to $8.76 \mathrm{~kg}$ in Hereford and $10.12 \mathrm{~kg}$ in Angus whereas the genetic range of Blonde d'Aquitaine was $14.14 \mathrm{~kg}$. The mean differences of the three breeds were given in the units of $\sigma_{\mathrm{G}}$ of the Angus breed. The approximate range for breeds was estimated to be $8.19 \sigma_{\mathrm{G}}(13.84 \mathrm{~kg})$ between Hereford and Piemontese. The breeding value of the heaviest Hereford were not expected to equal that of the lightest Piemontese animals. Both sources of genetic variation between and within breeds were large and important for birth weight. When both between and within breed genetic variations were considered, the range of genetic levels from the smallest Hereford to the heaviest Piemontese was estimated to be 25.75 $\mathrm{kg}$, or $83 \%$ of the average of the 2 breed means.

For weights at 210 and 365 days and daily gains from birth to 210 and 365 days the frequency curves of Hereford, Czech Pied and Blonde d'Aquitaine overlapped. For daily gains from 210 to 365 days the frequency curves of Hereford, Piemontese and Blonde d'Aquitaine overlapped too. For weight at 210-days the range of breed means was estimated to be about $2.58 \sigma_{\mathrm{G}}$ between Blonde d'Aquitaine and Czech Pied and $2.43 \sigma_{\mathrm{G}}$ between Czech Pied and Hereford. The range of breeding values from the smallest Hereford to the heaviest Blonde d'Aquitaine was estimated to be $184.68 \mathrm{~kg}$, or $79 \%$ of the average of the 2 breed means.

For weight at 365-days the range of breed means was found to be about $1.68 \sigma_{\mathrm{G}}$ between Blonde d'Aquitaine and Czech Pied, $2.34 \sigma_{\mathrm{G}}$ between Czech Pied and Hereford and $4.02 \sigma_{\mathrm{G}}$ between Blonde d'Aquitaine and Hereford. Both sources of genetic variation between breed and within breed were large and important for this trait. When both sources of genetic variation were considered, the range in breeding value from the smallest Hereford to the heaviest Blonde d'Aquitaine was estimated to be $313.21 \mathrm{~kg}$, or $86 \%$ of the average of the 2 breed means. For the weights at 210 - and 365-days the genetic frequency curves were only moderately shifted from Hereford to Czech Pied and Blonde d'Aquitaine. Genetic variation between and within breeds was large for all weights.

Ranking for daily gain from birth to 210-days and from birth to 365 days (Fig. 4) corresponded closely to those for the 210-day and 365-day weight. For daily gain from birth to 210-days the range for breed means was to be about $2.25 \sigma_{\mathrm{G}}$ between Blonde d'Aquitaine and Czech Pied, $1.67 \sigma_{\mathrm{G}}$ between Czech Pied and Hereford and $3.92 \sigma_{\mathrm{G}}$ between Blonde d'Aquitaine and Hereford. The range in genetic level from the smallest Hereford to the heaviest Blonde d'Aquitaine was estimated to be $0.87 \mathrm{~kg}$, or $89 \%$ of the average of both breed means. Genetic variation between breeds $\left(3.92 \sigma_{\mathrm{G}}\right)$ was much smaller for this trait compared to the genetic variation for the 210-day weight $\left(8.19 \sigma_{\mathrm{G}}\right)$. On the other hand, when both between and within breed genetic variations were considered as a ratio between the range in breeding value from the smallest Hereford to Blonde d'Aquitaine and the mean of both breeds, the variation in the daily gain from birth to 210 days $(89 \%)$ was higher than for the 210 -day weight (83\%). 
For daily gain from birth to 365-days the range for breed means was about $1.81 \sigma_{\mathrm{G}}$ between Blonde d'Aquitaine and Czech Pied, $1.84 \sigma_{\mathrm{G}}$ between Czech Pied and Hereford and $3.65 \sigma_{\mathrm{G}}$ between Blonde d'Aquitaine and Hereford. Genetic variation between breeds $\left(3.65 \sigma_{\mathrm{G}}\right)$ was substantially smaller for this trait compared to the genetic variation for 365 -day weight $\left(5.01 \sigma_{\mathrm{G}}\right)$. When both between and within breed genetic variation were considered as a ratio between the range in breeding value from the smallest Hereford to the largest Blonde d'Aquitaine and the mean of both breeds, the variation in daily gain from birth to 365 days $(0.89 \mathrm{~kg}, 95 \%)$ was higher than in 365-day weight (86\%).
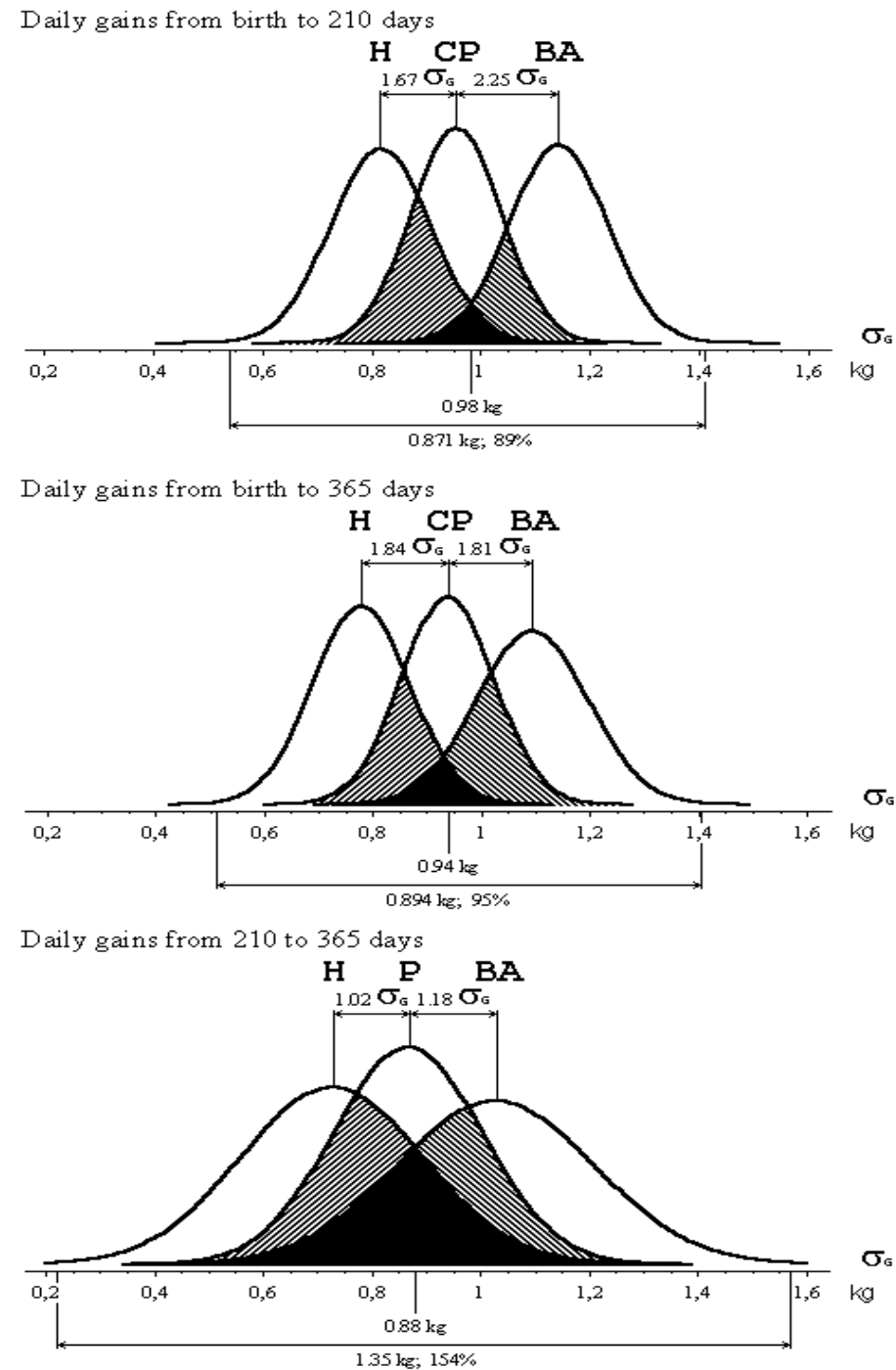

Fig. 4: Frequency curves of three breeds characterizing minimum, maximum and average daily gains (variation between and within breeds) [Normalverteilungskurven von drei Rassen mit minimalen, maximalen und durchschnittlichen Gewichten (Variation innerhalb und zwischen Rassen)]

For daily gain from 210 to 365-days the range for breed means was about $1.18 \sigma_{\mathrm{G}}$ between Blonde d'Aquitaine and Piemontese, $1.02 \sigma_{\mathrm{G}}$ between Piemontese and Hereford and $2.20 \sigma_{\mathrm{G}}$ between Blonde d'Aquitaine and Hereford. It was evident that the variation between the breed means was very low compared to the between breed variation of the other traits. When both between and within breed genetic variation were considered as a ratio between the range in breeding value from the smallest 
Hereford to the largest Blonde d'Aquitaine and the mean of both breeds, the between and within breed genetic variation in daily gain from 210 to 365 days, the value of $1.35 \mathrm{~kg}$ or $154 \%$ was the highest in comparison with the same values of the other traits. The between breed variation for body weights was much higher than for daily gains. THIESSEN et al. (1984) also found a much higher between-breed variation when expressed as a proportion of total variation for body weights than for daily gains. Body weights seem to be a better inter-breed selection criterion than daily gains. CUNDIFF et al. (1986b) confirmed the results of THIESSEN et al. (1984). They found for birth weight that the heritability between breeds was substantially higher than the heritability within breeds for the same trait. The between and within breed variation considered as a ratio between the range in breeding value from the smallest Hereford to the largest Blonde d'Aquitaine and the mean of both breeds on average was higher for daily gain than for body weight. Therefore, the total variation in growth traits between and within breeds is an important source for genetic improvement in growth traits.

Generally, significant genetic change can result from selection between and within breeds. Between breed differences can be more easily exploited than genetic variation within breeds because they are more heritable. Breeds can be selected to optimize performance levels for growth traits with a high level of precision much more quickly than through selection within breeds. Thus, when many breeds are at disposal, the between breed variation should be exploited by selection of the desired breeds for purebreeding, crossbreeding or for the foundation of synthetic (composite) populations. Simultaneously, the intrapopulation variation must be used. Intrapopulation variation is virtually restored generation after generation by the Mendelian process, while variation between populations, accruing only slowly as a result of different selection goals, genetic drift (associated with inbreeding) or rare mutation, cannot be exploited continuously. Although intrapopulation genetic variation should have the largest long-term impact on genetic change for specific objectives, opportunity to optimize performance levels by selection between breeds is great and response is immediate.

\section{References}

CUNDIFF, L.V.; GREGORY, K.E.; KOCH, R.M.; DICKERSON, G.E.:

Genetic diversity among cattle breeds and its use to increase beef production efficiency in a temperate environment. Proc. $3^{\text {rd }}$ World Congr. on Genet. Appl. to Livestock Prod., Lincoln, NE. USA, IX. 1986a, 271-282

CUNDIFF, L.V.; MACNEIL, M.D.; GREGORY, K.E.; KOCH, R.M.:

Between and within-breed genetic analysis of calving traits and survival to weaning in beef cattle. J.Anim. Sci., 63 (1986b), 27-33

JAKUBEC, V.; GOLDA, J.; ŘÍHA, J.: Beef cattle breeding. (Czech Language). VÚCHS - Rapotín (1998), 184 p.

JAKUBEC, V.; RIHA, J.; GOLDA, J.:

Analysis of factors affecting pre- and post-weaning traits of Angus, Blonde d'Aquitaine, Czech Pied, Hereford, Charolais, Limousin, Piemontese and Simmental calves in the Czech Republic. (Czech Language). Annual Report of the NAZV of the Czech Republic Projects no. EP 6538, 9063, 2000.

KOCH, R.M.; CUNDIFF, L.V.; GREGORY, K.E.: Beef cattle breed resource utilization. Rev. Brasil. Genet. 12, 3-Supplement (1989), 55-80

MÉNISSIER, F.; FRISCH, J. E.:

Genetic improvement of beef cows. In: JARRIGE, R.; BÉRANGER, C. (Editors). Beef cattle production. Elsevier, Amsterdam - London - New York - Tokyo (1992), 55-85

RENAND, G.; PLASSE, D.; ANDERSEN, B.B.: 
Genetic improvement of cattle growth and carcass traits. In: JARRIGE, R., BÉRANGER, C. (Editors). Beef cattle production. Elsevier, Amsterdam - London - New York - Tokyo (1992), 87-110

SZABÓ, F.; CUNDIFF, L.V.; GREGORY, K.E.; KOCH, R.M.; CROUSE, J.D.:

Breed differences in the reproduction traits of beef cattle. $45^{\text {th }}$ Meeting of EAAP, Edinburgh 5-8. IX. 1994, 10p.

TAYLOR, ST.C.S.:

Multibreed designs. 1. Variation between breeds. Anim Prod., 23 (1976a), 133-144

TAYLOR, ST.C.S.:

Multibreed designs. 2. Genetic variation within and between breeds. Anim. Prod., 23 (1976b), 145-154

THIESSEN, R.B.; HNIZDO, EVA; MAXWELL, D.A.G., GIBSON, D., TAYLOR, ST C.S.:

Multibreed comparison of British cattle. Variation in body weight, growth rate and food intake. Anim. Prod., 38 (1984), 323-340

Received: 2002-12-23

Accepted: 2003-02-24

Author's addresses

Prof. VÁCLAV JAKUBEC, DrSc., Doz. Mgr. IVAN MAJZLÍK, CSc.

Czech University of Agriculture, Faculty of Agronomy

Department of Genetics and Animal Breeding

Kamýcká 129

16521 Prague 6

Czech Republic

Prof. Dr. WERNER SCHLOTE

Humboldt-Universität zu Berlin, Institut für Nutztierwissenschaften

Invalidenstrasse 42

D-10115 Berlin

Germany

Prof. JAN ŘÍHA, DrSc.

Výzkumný ústav pro chov skotu Rapotín

78813 Vikýřovice

Czech Republic 